\title{
Recurrent lymphocytic myocarditis in a young male with ulcerative colitis
}

\author{
Varnavas C Varnavas ${ }^{1 *}$, Nico Reinsch ${ }^{1}$, Mareike Perrey ${ }^{1}$, Felix Nensa ${ }^{2}$, Thomas Schlosser ${ }^{2}$, Hideo A Baba ${ }^{3}$, \\ Guido Gerken ${ }^{4}$, Raimund Erbel ${ }^{1}$, Rolf A Janosi ${ }^{1}$ and Antonios Katsounas ${ }^{4}$
}

\begin{abstract}
Awareness of myocarditis in association with inflammatory bowel diseases is crucial as it bears a rare but serious risk for mortality. This report describes the case of a young Caucasian male, whose heart biopsy was tested negative for giant cells and bacterial or viral genomes or proteins. He was experiencing severe lymphocytic myocarditis (other than mesalamine-induced) along with cardiogenic shock during ulcerative colitis exacerbation. This is an extremely rare, if not unique, clinical constellation. We chose to study the epidemiologic grounds and all major aspects of differential pathogenesis and treatment of this serious health problem.
\end{abstract}

Keywords: Ulcerative colitis, lymphocytic myocarditis, heart failure

\section{Background}

Awareness of myocarditis, pericarditis or myopericarditis [1] in association with inflammatory bowel diseases (IBD), e.g. ulcerative colitis (UC) and Crohn's disease, is crucial, as they convey a rare but serious risk for mortality. The onset of symptoms often occurs during IBD exacerbation and prognosis varies from a mild cardiac disorder to severe cardiogenic shock. To date, most of the cases reported in association with IBD (other than infectious or 'giant cell' myocarditis), consider the myocarditis as a side effect of mesalamine therapy [2]. Lymphocytic myocarditis as a pure extraintestinal manifestation of IBD is extraordinarily rare [3].

\section{Case presentation}

A 30-year-old Caucasian male with a one-year history of UC was admitted to our intensive care unit (ICU) due to acute heart failure from an external hospital, where he had presented with abdominal pain and bloody diarrhea two weeks previously. These symptoms were assumed to arise from UC exacerbation. Prednisone $(1 \mathrm{mg} / \mathrm{kg}$-bodyweight/day) and azathioprine $(2 \mathrm{mg} / \mathrm{kg}$-body-weight/ day) had been added to the standard therapy with mesalamine $(4 \mathrm{~g} /$ day $)$. Ten days later, the patient rapidly

\footnotetext{
* Correspondence: Varnavas.Varnavas@uk-essen.de

${ }^{1}$ Department of Cardiology, University Hospital Essen, Hufelandstrasse 55, 45147 Essen, Germany

Full list of author information is available at the end of the article
}

developed aggravated symptoms of left heart failure. A transthoracic cardiac echocardiogram (TTE) confirmed severe impairment of left ventricular (LV) function with the ejection fraction (EF) approaching 15\%, before the patient was referred to our ICU.

On ICU admission, a 12-lead electrocardiogram (ECG) detected sinus tachycardia of 100/min and non-specific ST-T wave changes without any significant evidence of acute myocardial ischemia. A chest X-ray showed no pulmonary infection. TTE verified LV dysfunction with advanced hypokinesia to akinesia of the basal/middle-inferior/septal/anterior wall resulting in an $\mathrm{EF}$ of $13 \%$ and revealed pericardial effusion (PE) of $1.6 \mathrm{~cm}$ (Figure 1A,B). These findings were accompanied by abnormal laboratory tests including anemia (hemoglobin: $7.6 \mathrm{~g} / \mathrm{dl}$ ), leukocytosis $(16.25 / \mathrm{nl})$ and elevated levels of C-reactive protein (27.6 $\mathrm{mg} / \mathrm{dl})$, troponin-I $(7.6 \mathrm{ng} / \mathrm{ml})$, myoglobin $(664 \mathrm{~g} / \mathrm{dl})$, brain natriuretic peptide $(4744.7 \mathrm{pg} / \mathrm{ml})$, creatinine $(1.43 \mathrm{mg} / \mathrm{dl})$, lactate dehydrogenase $(565 \mathrm{U} / \mathrm{l})$, aspartate aminotransferase $(253 \mathrm{U} / \mathrm{l})$, alanine aminotransferase $(166 \mathrm{U} / \mathrm{l})$ and gamma-glutamyl transpeptidase (119 U/l). Table 1 shows the initial as well as follow-up routine biochemistry parameters along with in-house-specific reference values.

Invasive blood pressure monitoring and pulmonary artery catheterization (via a Swan-Ganz catheter) were used to record hemodynamic variables. Subsequently, dobutamine $(15 \mu \mathrm{g} / \mathrm{kg}$ body weight $/$ minute) was administered because of deranged cardiac output $(1.8 \mathrm{l} / \mathrm{min})$ 

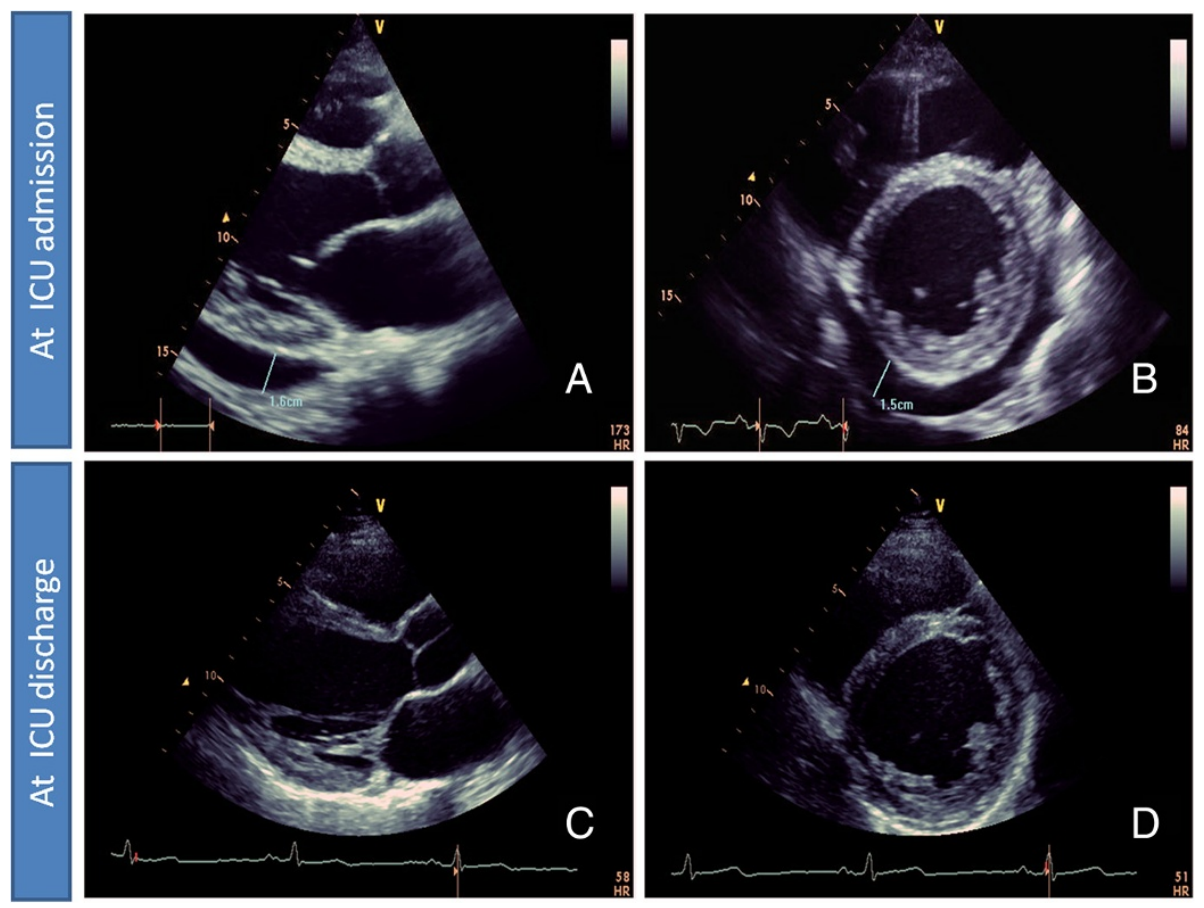

Figure 1 Transthoracic cardiac echocardiogramms. At ICU admission: (A) long axis view, and (B) short axis view; both views show a pericardial effusion of $1.6 \mathrm{~cm}$. At ICU discharge: (C) long axis view, and (D) short axis view; both views confirm significant reduction of pericardial effusion.

and cardiac index $\left(0.8 \mathrm{l} / \mathrm{min} / \mathrm{m}^{2}\right)$. However, due to undesirable tachycardia, the dobutamine was switched to milrinone $(0.75 \mu \mathrm{g} / \mathrm{kg}$-body-weight/minute). On grounds of insufficient inotropic drug efficacy in line with unchanged cardiac output and cardiac index measurements and echocardiographic findings, as well as lack of clinical improvement, the use of an intra-aortic balloon pump (ECG-triggered) was considered mandatory.

While no evidence of myocardial infarction or coronary artery disease was found in the left heart, right cardiac catheterization revealed an elevated mean pulmonary artery pressure of $33 \mathrm{mmHg}$ (a mean value of $15 \mathrm{mmHg}$ is considered normal) and multiple myocardial biopsies were acquired.

Histological examination revealed acute myocarditis with lymphocytic infiltration. No neutrophile granulocytes or giant cells were found (Figure 2A). Furthermore, PCR analysis of the tissue did not detect any adenovirus DNA, parvovirus B19 DNA, human herpesvirus 6 DNA, Epstein-Barr virus DNA, varicella zoster virus DNA, herpes simplex virus DNA, cytomegalovirus DNA or enterovirus RNA including Coxsackie $A$ virus and Coxsackie $B$ (1-6) virus. In addition, immunohistochemical analysis did not detect any cytomegalovirus-associated proteins. The patient tested negative for HIV infection based on detection of specific antibodies (via ELISA) as well as RNA (via PCR) in serum.
In consideration of the patient's critical condition and the persistently high levels of serum inflammatory markers, the patient was started on empiric antibiotic coverage consisting of intravenous piperacillin/tazobac$\operatorname{tam}(3 \times 4.5 \mathrm{~g} /$ day over 10 days $)$.

While awaiting systemic infection (diagnostic) results, azathioprine was paused. Further immunological and infection parameters pertinent to myocarditis were measured: rheumatoid factor (negative, <10.3 IU/ml) and antinuclear and anti-centromere antibody levels (ANA negative, HEP2-IFT <1:80; c-ANCA and p-ANCA negative, ANCA-IFT <1:10). All blood cultures collected within 3 days of admission were negative for bacterial and fungal growth.

Nine days later, the intra-aortic balloon pump was removed after gradual tapering off of milrinone accompanied by normalization of hemodynamic parameters, e.g. cardiac output was $8 \mathrm{l} / \mathrm{min}$ and cardiac index was $3.7 \mathrm{l} /$ $\mathrm{min} / \mathrm{m}^{2}$. At day 15 of ICU treatment, a TTE confirmed improved LV function with an EF of $50 \%$ as well as elimination of the PE (Figure 1C, D) and the patient was discharged to a ward. At this point, cardiac magnetic resonance imaging (MRI) was performed, which confirmed myocarditis along with tissue edema and moderate PE $(0.3 \mathrm{~cm})$; however, no late enhancement was detected. Subsequently, the heart failure therapy, i.e. bisoprolol (10 $\mathrm{mg} /$ day), ramipril (2.5 $\mathrm{mg} /$ day) and spironolactone 
Table 1 Initial and follow-up biochemistry values based on routine diagnostic tests

\begin{tabular}{|c|c|c|c|c|c|c|}
\hline Parameter & $\begin{array}{c}\text { Initial } \\
\text { admission }\end{array}$ & $\begin{array}{c}\text { Initial } \\
\text { discharge }\end{array}$ & Readmission & $\begin{array}{c}\text { Final } \\
\text { discharge }\end{array}$ & Reference & Unit \\
\hline Leucocytes (WBCs) & 16.25 & 9.11 & 8.71 & 6.78 & $3.6-9.2$ & $/ \mathrm{nl}$ \\
\hline Red Blood Cells (RBCs) & 2.63 & 4.14 & 4.97 & 5.08 & $4.5-5.6$ & $/ p l$ \\
\hline Hemoglobin (Hb) & 7.60 & 12.00 & 14.30 & 14.6 & $13.7-17$ & $\mathrm{~g} / \mathrm{dl}$ \\
\hline Hematocrit (Hct) & 0.22 & 0.37 & 0.42 & 0.421 & $0.4-0.5$ & $1 / 1$ \\
\hline Mean Corpuscular Volume (MCV) & 82.90 & 89.40 & 83.70 & 82.9 & $83-98$ & $\mathrm{fl}$ \\
\hline Mean Corpuscular Hemoglobin (MCH) & 28.90 & 29.00 & 28.80 & 28.7 & $28-33$ & $\mathrm{pg}$ \\
\hline Mean Corpuscular Hemoglobin Concentration (MCHC) & 34.90 & 32.40 & 34.40 & 34.7 & $32-36$ & $\mathrm{~g} / \mathrm{dl}$ \\
\hline Platelets & 499 & 321 & 263 & 224 & $140-320$ & $/ \mathrm{nl}$ \\
\hline Mean Platelet Volumen (MPV) & 9.00 & 9.20 & 9.70 & 10.2 & $9.4-12.2$ & $\mathrm{fl}$ \\
\hline Prothrombin Time (PT or Quick) & 48 & 96 & 98 & 97 & $70-130$ & $\%$ \\
\hline International Normalized Ratio (INR) & 1.45 & 1.04 & 1.02 & 1.02 & & \\
\hline Activated Partial Thromboplastin Time (aPTT) & 28.60 & 26.30 & 27.10 & 26.8 & 24.4-32 & $\mathrm{sec}$ \\
\hline Fibrinogen & 557 & 448 & 566 & 386 & $210-400$ & $\mathrm{mg} / \mathrm{dl}$ \\
\hline Sodium & 127 & 138 & 142 & 142 & $136-145$ & $\mathrm{mmol} / \mathrm{l}$ \\
\hline Potassium & 5.60 & 4.80 & 4.60 & 4.7 & $3.5-5.1$ & $\mathrm{mmol} / \mathrm{l}$ \\
\hline Calcium & 1.94 & 2.29 & 2.38 & 2.48 & $2.08-2.6$ & $\mathrm{mmol} / \mathrm{l}$ \\
\hline Magnesium & 0.78 & 0.83 & 0.79 & 0.81 & $0.66-1.0$ & $\mathrm{mmol} / \mathrm{l}$ \\
\hline Phosphate & 4.40 & 4.40 & 2.80 & 3.2 & $2.7-4.5$ & $\mathrm{mg} / \mathrm{dl}$ \\
\hline Creatinine & 1.43 & 0.84 & 1.24 & 1.32 & $0.9-1.3$ & $\mathrm{mg} / \mathrm{dl}$ \\
\hline Blood Urea Nitrogen (BUN) & 42.00 & 21.00 & 22.00 & 22 & $6-19.8$ & $\mathrm{mg} / \mathrm{dl}$ \\
\hline Creatinine Kinase (CK) & 418 & 13 & 45 & 59 & $38-174$ & $\mathrm{U} / \mathrm{I}$ \\
\hline Creatinine Kinase -MB (CK-MB) & 61 & & & & $<25$ & $\mathrm{U} / \mathrm{I}$ \\
\hline Creatinine Kinase -MB\% (CK-MB \%) & 15 & & & & & $\%$ \\
\hline Troponin I & 7.60 & 0.04 & 0.42 & 0.08 & $0-0.1$ & $\mathrm{ng} / \mathrm{ml}$ \\
\hline Myoglobin & 664 & 21 & 30 & 20 & $10-67$ & $\mu g / l$ \\
\hline Aspartat Aminotransferase (ASAT) & 253 & 19 & 15 & 21 & $0-<50$ & $\mathrm{U} / \mathrm{I}$ \\
\hline Alanine Aminotranseferase (ALAT) & 166 & 40 & 28 & 42 & $<50$ & $\mathrm{U} / \mathrm{l}$ \\
\hline Gamma-glutamyl transpeptidase (GGT) & 119 & 79 & 33 & 84 & $<55$ & $\mathrm{U} / \mathrm{l}$ \\
\hline Lactate dehydrogenase (LDH) & 565 & 183 & 142 & 138 & $100-247$ & $\mathrm{U} / \mathrm{l}$ \\
\hline C-reactive protein (CRP) & 27.60 & 0.70 & 4.10 & 0.6 & $<0.5$ & $\mathrm{mg} / \mathrm{dl}$ \\
\hline Brain natriuretic peptide (BNP) & 4744.70 & 462.30 & 108.60 & 60.5 & $0-100$ & $\mathrm{pg} / \mathrm{ml}$ \\
\hline Glomerular Filtration Rate (GFR) (MDRD) & 62 & 114 & 73 & 68 & & $\mathrm{ml} / \mathrm{min} / 1.73$ \\
\hline
\end{tabular}

(25 mg/day), was adjusted in a stepwise fashion based on hemodynamic parameters and clinical improvement and the patient was discharged after full recovery to ambulant treatment. Of note, the systemic therapy with mesalamine was never interrupted. Because of the active colitis, additional systemic therapy with acetylsalicylic acid was not taken into consideration after discharge from the hospital.

Six months after the first incident, the patient presented to our hospital with mild dyspnea on exertion and slight abdominal pain without bloody diarrhea. On admission, medication consisted of mesalamine ( $4 \mathrm{~g} /$ day) and budesonide (rectal foam, $2 \mathrm{mg} /$ day). His blood pressure levels and serial ECG reports were normal. An X-ray showed no pulmonary infection. A TTE revealed a stable LV function (EF 50\%); however, moderate PE (0.8 $\mathrm{cm}$ ) was observed (Figure 3). Laboratory tests demonstrated slight elevations of inflammatory parameters and brain natriuretic peptide (Table 1). Thus, we promptly assumed that the beginning of an UC re-exacerbation might have triggered recurrent myocarditis. Unfortunately, the patient declined colonoscopy. As expected, a follow-up cardiac MRI revealed anterior LV wall edema along with PE $(1.2 \mathrm{~cm})$ and lateral wall late enhancement, indicative of acute myocarditis (Figures 4, 5 and 6). Again, 


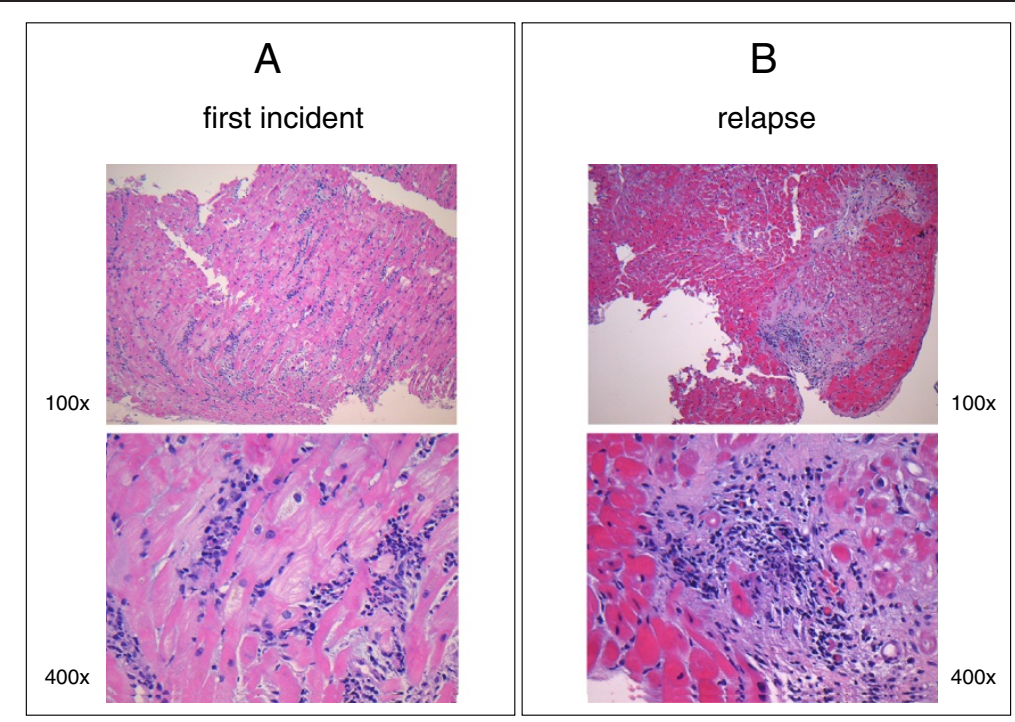

Figure 2 Histology images revealed acute myocarditis with lymphocytic infiltration and moderate myocyte apoptosis at first onset (A) and relapse (B). These biopsies did not detect giant cells or significant neutrophile infiltrates.

myocardial biopsies were obtained, which showed the same pattern of lymphocytic myocarditis (Figure 2B). This time, the patient's clinical condition improved on administering prednisone ( $1 \mathrm{mg} / \mathrm{kg}$-body-weight/day), bisoprolol (10 $\mathrm{mg} /$ day), ramipril $(2.5 \mathrm{mg} /$ day $)$ and spironolactone (25 mg/day). After discharge, a 6-month follow-up TTE showed normal LV function and no PE.

\section{Conclusions}

An association of cardiac disease with IBD has rarely been found [2]. In a large nationwide study of IBD patients $(N=15,572)$ conducted from 1977 to 1992 in Denmark, the incidence of myocarditis was $0.03 \%$ [2]. In these cases, the most frightening scenario is finding giant cells in a biopsy. Giant cell myocarditis, which often coincides with autoimmune diseases, has been reported as inevitably fatal with a fulminate course resulting in death, usually within 3 months [4-6]. To date, less than five cases have been reported in the literature of IBD-related myocarditis (other than giant cell myocarditis) that rapidly ends in severe heart failure during UC exacerbation for either new onset or relapse cases. This convinced us of the need to report this case of a young male experiencing severe lymphocytic myocarditis along with left heart failure during UC exacerbation.

Lymphocytic myocarditis emerges through an interstitial influx of lymphocytes followed by consecutive myocyte apoptosis [4]. Apparently, lymphocytic infiltrates have been observed in most cases of biopsy-verified myocarditis. Of these, the positive detection of

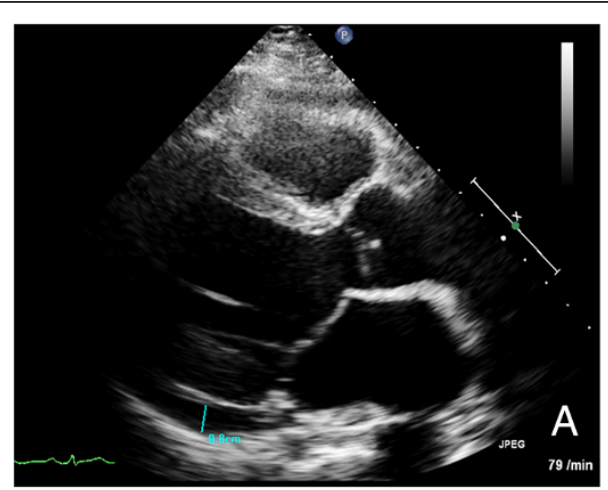

Figure 3 Transthoracic cardiac echocardiogramms. (A) Long axis view. at readmission.

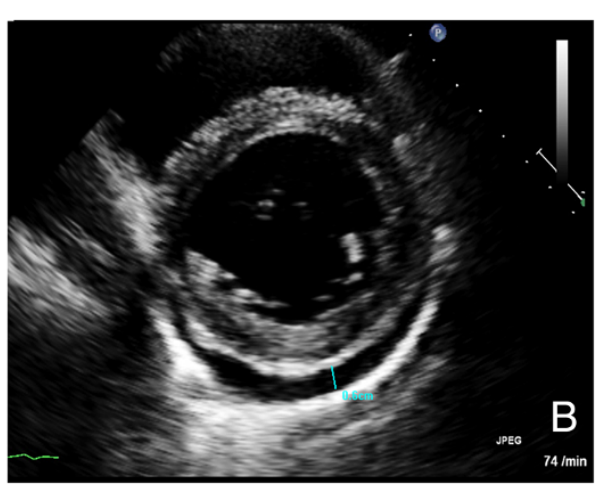

(B) Short axis view. These views show a pericardial effusion of $0.8 \mathrm{~cm}$ 

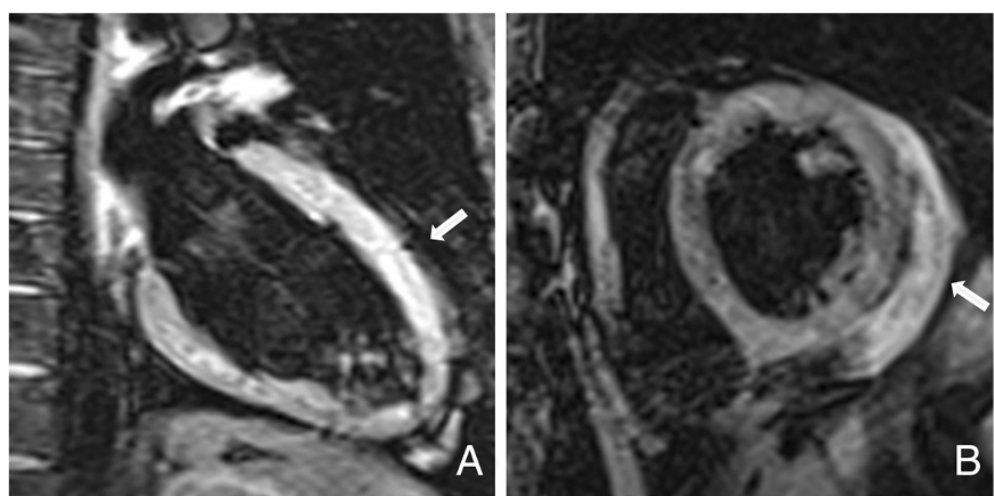

Figure 4 Cardiac magnetic resonance imaging (MRI), turbo inversion recovery magnitude (TIRM) sequence. (A) Edema in anterior wall. (B) Pericardial effusion of $1.2 \mathrm{~cm}$.

circulating cardiac auto-antibodies and/or viral genomes in myocardial biopsy specimens or bacterial or fungal systemic infections represent the most trivial findings in patients experiencing active IBD-related lymphocytic myocarditis (reviewed in $[3,4,7]$ ). Biopsy results for our patient were negative for viral genomes or proteins. No bacterial or fungal infections were found in peripheral blood during all stays or follow-up visits in our hospital. Azathioprine was paused on first admission to the ICU as it is of unproven benefit for myocarditis other than for giant cell myocarditis [4]. Therefore, both times acute phase immunosuppressive therapy was confined to systemic therapy with prednisone [7-9]. Because of the symptoms of co-emergent severe colitis, systemic therapy with prednisone was considered mandatory. In any other case, intrapericardial treatment with triamcinolone, especially in patients with perimyocarditis, would be an equally effective local therapy option [10]. Interestingly, 6 months after the first incident, the patient's cardiac function deteriorated after discontinuation of prednisone [7] (Figure 7). This event had clinical, TTE, MRI and histological evidence of recurrent myocarditis, which
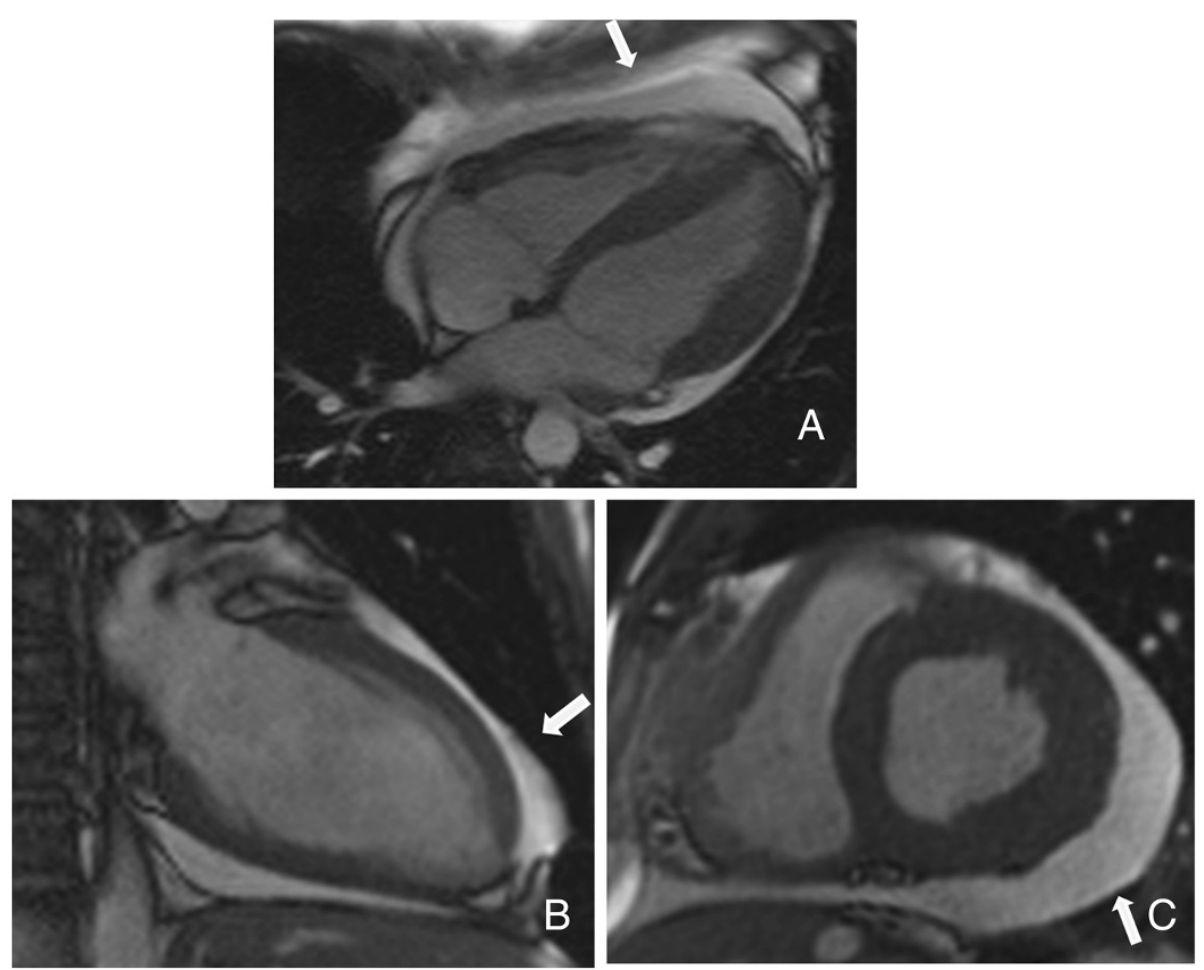

Figure 5 Cardiac magnetic resonance imaging (MRI), balanced steady-state free precesion (bSSFP) sequence. (A-C) These images show pericardial effusion of $1.2 \mathrm{~cm}$. 

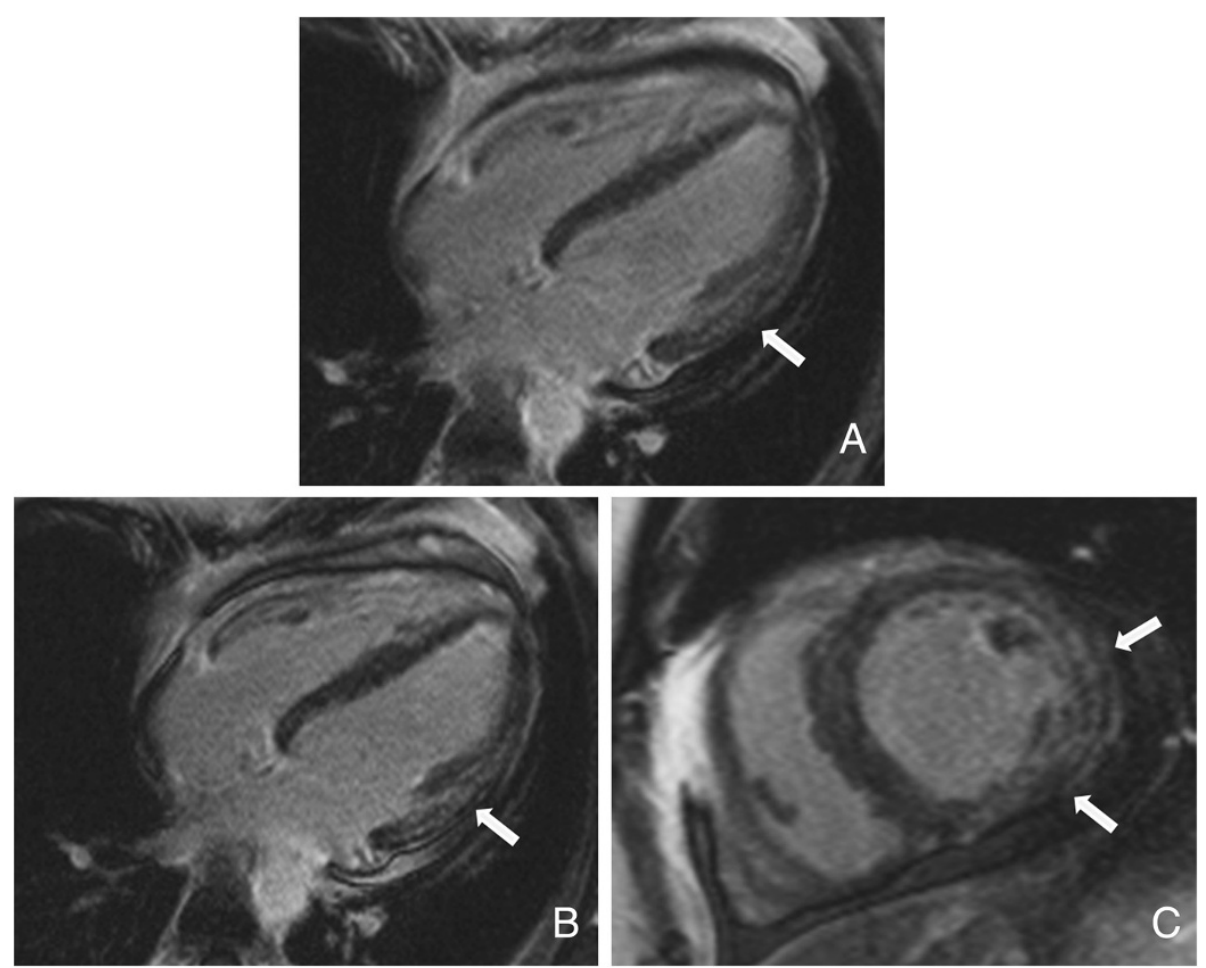

Figure 6 Cardiac magnetic resonance imaging (MRI), inversion recovery (IR) turbo fast low-angle shot (FLASH) sequence. (A) Beginning enhancement in lateral wall. (B-C) Intramural late-enhancement in lateral wall.

improved after recontinuation of immunosuppressive therapy and is consistent with data published elsewhere [7].

IBD-related cardiac disease may also occur as mesalamineinduced myocarditis. This form of myocarditis, where eosinophilic infiltration can be observed on a biopsy, has previously been described as a mechanism of drug hypersensitivity, and the symptoms are milder [11]. Here, mesalamine-induced myocarditis is unlikely since mesalamine administration was never interrupted. Moreover,

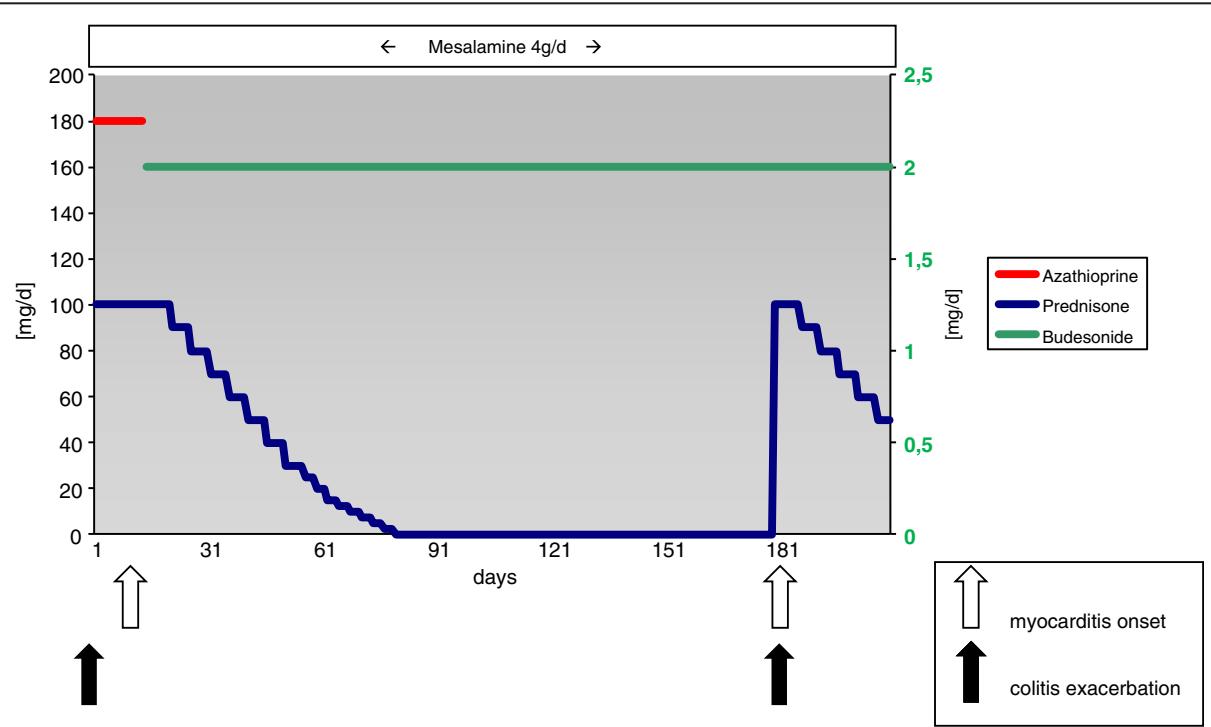

Figure 7 Medication curves. The graph illustrates dose and application time of systemic treatment with prednisone, azathioprine and mesalamine and local therapy with budesonide during the entire observation period. This graph also indicates the time points of clinical exacerbation of ulcerative colitis along with emergence of myocarditis symptoms. 
according to the Naranjo Nomogram, it is doubtful that these episodes of myocarditis were due to mesalamine [12].

\section{Consent}

Written informed consent was obtained from the patient for publication of this case report and the accompanying images. A copy of the written consent is available for review by the editor-in-chief of this journal.

\section{Abbreviations}

ANA: antinuclear antibody; ANCA: anti-centromere antibody; ECG: electrocardiogram; EF: ejection fraction; ELISA: enzyme-linked immunosorbent assay; IBD: inflammatory bowel disease; LV: left ventricle; MRI: magnetic resonance imaging; PCR: polymerase chain reaction; PE: pericardial effusion; TTE: transthoracic cardiac echocardiogram; UC: ulcerative colitis

\section{Competing interests}

The authors report no conflicts of interest. The authors alone are responsible for the content and writing of the paper.

\section{Authors' contributions}

VCV wrote the manuscript. AK was involved in the drafting, editing, correction and supervising of this paper. AK, VCV, NR and RAJ diagnosed and treated the patient. MP provided the TTE images. TS and FN provided the MRI images. HAB provided the histological data and images. GG and RE assisted as experts. All authors read and approved the final manuscript.

\section{Author details}

'Department of Cardiology, University Hospital Essen, Hufelandstrasse 55, 45147 Essen, Germany. ${ }^{2}$ Institute of Diagnostic and Interventional Radiology, University Hospital Essen, Hufelandstrasse 55, 45147 Essen, Germany. ${ }^{3}$ Institute of Pathology and Neuropathology, University Hospital Essen, Hufelandstrasse 55, 45147 Essen, Germany. ${ }^{4}$ Department of Gastroenterology and Hepatology, University Hospital Essen, Hufelandstrasse 55, 45147 Essen, Germany.

Received: 17 October 2013 Accepted: 17 February 2014

Published: 27 February 2014

\section{References}

1. Mowat NA, Bennett PN, Finlayson JK, Brunt PW, Lancaster WM: Myopericarditis complicating ulcerative colitis. Br Heart J 1974, 36:724-727

2. Sorensen HT, Fonager KM: Myocarditis and inflammatory bowel disease. A 16-year Danish nationwide cohort study. Dan Med Bull 1997, 44:442-444

3. Freeman HJ, Salh B: Recurrent myopericarditis with extensive ulcerative colitis. Can J Cardiol 2010, 26:549-550.

4. Davidoff R, Palacios I, Southern J, Fallon JT, Newell J, Dec GW: Giant cell versus lymphocytic myocarditis. A comparison of their clinical features and long-term outcomes. Circulation 1991, 83:953-961.

5. Cooper LT Jr, Berry GJ, Shabetai R: Idiopathic giant-cell myocarditis natural history and treatment. N Engl J Med 1860-1866, 1997:336.

6. Davies MJ, Pomerance A, Teare RD: Idiopathic giant cell myocarditis - a distinctive clinico-pathological entity. Br Heart J 1975, 37:192-195.

7. Frustaci A, Chimenti C, Calabrese F, Pieroni M, Thiene G, Maseri A: Immunosuppressive therapy for active lymphocytic myocarditis: virological and immunologic profile of responders versus nonresponders. Circulation 2003, 107:857-863.

8. Mason JW, O'Connell JB, Herskowitz A, Rose NR, McManus BM, Billingham ME, Moon TE: A clinical trial of immunosuppressive therapy for myocarditis. N Engl J Med 1995, 333:269-275.

9. Wojnicz R, Nowalany-Kozielska E, Wojciechowska C, Glanowska G, Wilczewski P, Niklewski T, Zembala M, Polonski L, Rozek MM, Wodniecki J: Randomized, placebo-controlled study for immunosuppressive treatment of inflammatory dilated cardiomyopathy: two-year follow-up results. Circulation 2001, 104:39-45.
10. Maisch B, Seferovic PM, Ristic AD, Erbel R, Rienmuller R, Adler $Y$, Tomkowski WZ, Thiene G, Yacoub MH: Guidelines on the diagnosis and management of pericardial diseases executive summary. Eur Heart J 2004, 25:587-610.

11. Stelts S, Taylor MH, Nappi J, Van Bakel AB: Mesalamine-associated hypersensitivity myocarditis in ulcerative colitis. Ann Pharmacother 2008, 42:904-905.

12. Naranjo CA, Busto U, Sellers EM, Sandor P, Ruiz I, Roberts EA, Janecek E, Domecq C, Greenblatt DJ: A method for estimating the probability of adverse drug reactions. Clin Pharmacol Ther 1981, 30:239-245.

doi:10.1186/2047-783X-19-11

Cite this article as: Varnavas et al:: Recurrent lymphocytic myocarditis in a young male with ulcerative colitis. European Journal of Medical Research 2014 19:11.

\section{Submit your next manuscript to BioMed Central and take full advantage of:}

- Convenient online submission

- Thorough peer review

- No space constraints or color figure charges

- Immediate publication on acceptance

- Inclusion in PubMed, CAS, Scopus and Google Scholar

- Research which is freely available for redistribution 